\title{
Features Smelting of Iron and Silicate Materials in the Solid Fuel Low Shaft Furnace
}

\author{
Andrey V. Feoktistov ${ }^{a}$, \\ Alexander P. Skuratov ${ }^{\mathrm{b}}$ and Ivan F. Selyanin ${ }^{\mathrm{a} *}$ \\ ${ }^{a}$ Siberian State Industrial University \\ 42 Kirov Str., Novokuznetsk, 654007, Russia \\ ${ }^{b}$ Siberian Federal University \\ 79 Svobodny, Krasnoyarsk, 660041, Russia
}

Received 23.06.2016, received in revised form 10.08.2016, accepted 13.10.2016

The process of smelting iron and silicate materials in the solid fuel low shaft furnace (cupola) by replacing coke by anthracite and lean coal. The theoretical and practical study of the basic technological parameters of the process. The optimal level of loading of materials in the smelting of iron and silicate materials in the solid-low shaft oven, a method of supplying oxygen into the blast zone of the furnace and the blast temperature.

Keywords: solid fuel low shaft furnace (cupola), coke, anthracite, lean coal, heated blast.

Citation: Feoktistov A.V., Skuratov A.P., Selyanin I.F. Features smelting of iron and silicate materials in the solid fuel low shaft furnace, J. Sib. Fed. Univ. Eng. technol., 2016, 9(7), 1104-1109. DOI: 10.17516/1999-494X-2016-9-7-1104-1109.

\section{Особенности плавки чугуна \\ и силикатных материалов \\ в твердотопливной низкошахтной печи}

\author{
А.В. Феоктистов ${ }^{\mathrm{a}}$, А.П. Скуратов ${ }^{\tilde{\sigma}}$, И.Ф. Селянин ${ }^{\mathrm{a}}$ \\ ${ }^{a}$ Сибирский государственный индустриальный университет \\ Россия, 654007, Новокузнеик, ул. Кирова, 42 \\ ${ }^{6}$ Сибирский федеральный университет \\ Россия, 660041, Красноярск, пр. Свободный, 79
}

Рассмотрен прочесс плавки чугуна и силикатных материалов в твердотопливной низкошахтной печи (вагранке) при замене кокса антрацитом и тощими углями. Приведено теоретическое и практическое обоснование основных технологических параметров процесса. Установлен оптимальный уровень загрузки материалов при плавке чугуна и силикатных

(C) Siberian Federal University. All rights reserved

* Corresponding author E-mail address: ol.berg@mail.ru 
материалов в твердотопливной низкочахтной печи, способ подачи дутья в кислородную зону печи и температура дутья.

Ключевые слова: твердотопливная низкошахтная печь (вагранка), кокс, антрацит, тощие угли, подогрев дутья.

Плавка литейных сплавов является первичным и ответственным технологическим переделом, обеспечивающим литейные, прочностные и эксплуатационные характеристики отливок. В последние годы недостаточное внимание уделяется совершенствованию технологии плавки чугуна в твердотопливной низкошахтной печи (вагранке). Вместе с тем низкошахтная печь в ряде случаев незаменима в условиях массового производства, при выплавке чугуна ограниченного марочного состава и возможности получения в ней оксидных расплавов с дальнейшей их переработкой в теплоизоляционные изделия, а также применяется при обжиге серных колчеданов и для других целей.

Основные направления развития ваграночного процесса - разработка ресурсосберегающих технологий плавки с применением заменителей кокса, интенсификация процесса за счет подогрева, увлажнения и обогащения кислородом дутья, что должно способствовать повышению температуры получаемого расплава.

Замена кокса более дешевым топливом позволит повысить технико-экономические показатели работы низкошахтных печей. Все большее распространение в качестве топлива получают антрацит и тощие угли, однако их применение в шахтных печах требует глубокой теоретической проработки и практической апробации.

Основной недостаток способа плавки с применением антрацита и тощих углей - их низкая термическая стойкость, вследствие чего при быстром нагреве в печи и значительном давлении столба шихтовых материалов образуется большое количество мелких фракций, что приводит к уменьшению свободного сечения печи и нарушению хода плавки. Растрескивание происходит вследствие высоких механических и термических напряжений в объеме куска топлива в кислородной зоне, где поверхность куска разогревается до $2200-2300^{\circ} \mathrm{C}$.

Задачей настоящего исследования является разработка технологии плавки чугуна и силикатных материалов в твердотопливной низкошахтной печи, позволяющей полностью заменить кокс антрацитом и тощими углями без нарушения технологического режима плавки. Экспериментальные плавки проводили в печи Новокузнецкого предприятия $3 \mathrm{AO}$ «Изолит». Печь внутренним диаметром 1250 мм имела два загрузочных окна на высоте 3,5 и 5,5 м от уровня основного ряда фурм. Она предназначена для приготовления оксидного расплава из отвального доменного шлака и горной породы - диабаза, используемого при производстве минераловатных изделий. В качестве топлива применяли антрацит марки А и тощие угли марки ТПКО ОАО ОФ «Разрез Красногорский» (юг Кузбасса). Печь оборудована радиационно-конвективным рекуператором, позволяющим подогревать дутье до $550{ }^{\circ} \mathrm{C}$. Предприятие работает на заменителях кокса в качестве топлива с 2005 г.

Цены на природный газ постоянно повышаются, поэтому с 2009 г. радиационноконвективный рекуператор был отключен и в трубу печи был установлен рекуператор по принципу «труба в трубе», конструкция которого разработана инженерно-техническими специалистами ЗАО «Изолит» совместно с группой сотрудников кафедры материаловедения, ли- 
тейного и сварочного производства Сибирского государственного индустриального университета. Конструкция рекуператора разрабатывалась поэтапно [1-4], что позволило в последнем варианте установки достигнуть подогрева дутья до 450-500 을

Плавка ведется на холостой колоше высотой $H_{\text {x.к }}=1000-1200$ мм от уровня вдувания воздуха. Сверху холостой колоши загружают послойно в шахту печи рабочие топливные колоши и колоши шихты, состоящей из диабаза и доменного шлака.

Следует подчеркнуть, что уровень вдувания материалов в печь от места подачи дутья для чугуноплавильных вагранок расположен на высоте $H_{\mathrm{B}}$, определяемой эмпирической зависимостью

$$
H_{B}=(4,25-4,30) \sqrt{D_{B}},
$$

где $D_{\text {в }}$ - внутренний диаметр печи [5].

Высокие уровень загрузки и температура куска топлива в кислородной зоне печи не позволяют вести технологически устойчиво плавку на антраците и тощих углях, теплотворная способность которых в 1,1-1,2 раза выше, а зольность в 1,3-1,5 раза ниже, чем кокса. Поэтому для ведения плавки с использованием антрацита и тощих углей уровень загрузки материалов в печи необходимо понизить, он должен составлять $(2,5-2,8) \sqrt{D_{B}}$, а дутье должно подаваться подогретым до $450-550{ }^{\circ} \mathrm{C}$ в равных количествах на двух горизонтах с расстоянием между ними $L_{12}=250 \mathrm{Mм}$ (рис. 1$)$.

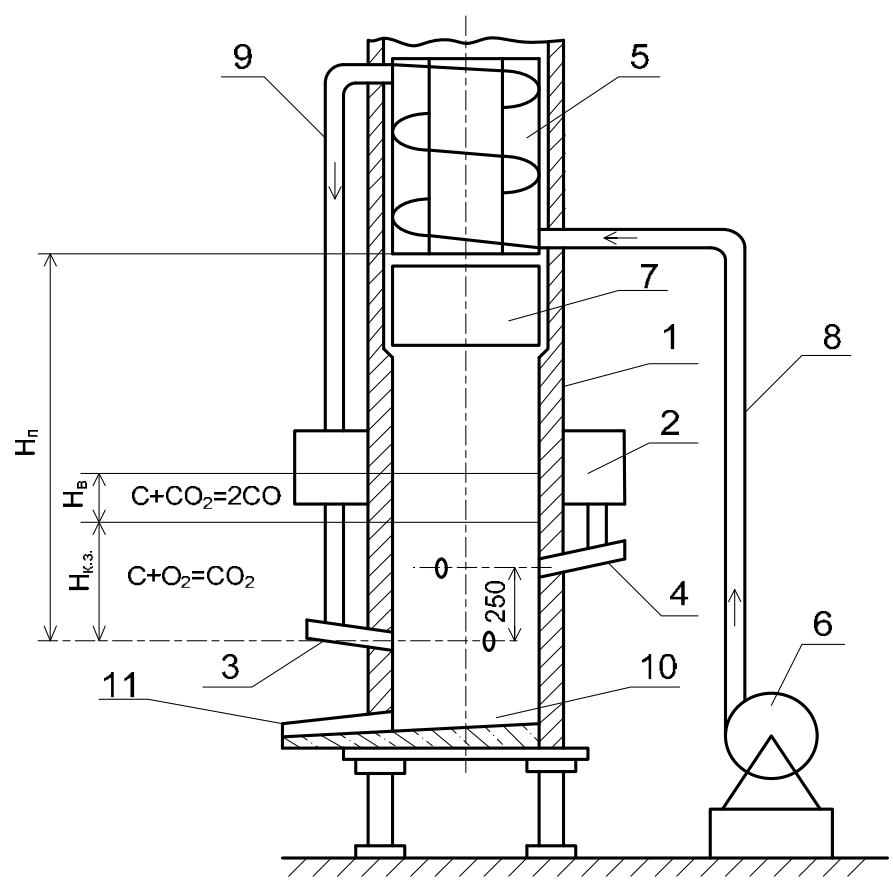

Рис. 1. Конструктивные элементы установки: 1 - шахта печи; 2 - фурменная коробка; 3 - фурмы нижнего ряда; 4 - фурмы второго ряда; 5 - рекуператор «труба в трубе»; 6 - воздуходувка; 7 - завалочное (загрузочное) окно; 8 - трубопровод холодного дутья; 9 - трубопровод горячего дутья; 10 - горн печи; 11 - летка для выпуска расплава; $\mathrm{H}_{\text {к.3. }}$ - высота кислородной зоны; $\mathrm{H}_{\mathrm{s}}$ - высота восстановительной (редукционной) зоны; $\mathrm{H}_{\text {п }}$ - полезная высота печи 
Для определения оптимальной высоты уровня загрузки материалов были выполнены необходимые теплотехнические расчеты [5], которые экспериментально подтверждены на производственной печи.

При высоте загрузки меньше $2,5 \sqrt{D_{B}}$ не достигается полного прогрева шихты до температуры плавления, наиболее крупные ее куски диаметром $D_{\text {ш }}>0,085$ м будут проваливаться в горн печи, резко охлаждая шлаковый расплав. При высоте загрузки больше $2,5 \sqrt{D_{B}}$ увеличивается давление столба шихты на холостую колошу из антрацита или тощих углей. Они начинают интенсивно истираться и растрескиваться, мелочь угля вместе с расплавом шлака образует мощные козырьки над фурмами, сопротивление столба материалов резко возрастает, уменьшается поступление дутья в печь, что приводит к снижению температуры выпускаемого расплава.

Второй уровень вдувания должен быть расположен в конце кислородной зоны первого уровня. По данным работы [6], длина $L_{\mathrm{\kappa}}$ кислородной зоны:

$$
L_{K}=A D_{K} \operatorname{Re}^{0,2},
$$

где $A$ - константа; $D_{\text {к }}$ - средний размер кусков топлива; $\mathrm{Re}$ - число Рейнольдса.

В соответствии с ГОСТ 24774-81 вагранки средней производительности имеют внутренний диаметр 900; 1100; 1300 мм. Для коксовой вагранки длина кислородной зоны составляет 350-400 мм [1], что соответствует $L_{K}=1,165 \sqrt{D_{B}}$ [5]. Куски углей при опускании в кислородную зону частично истираются и дробятся, их средний размер примерно в два раза меньше размера кусков кокса, они занимают пространство между уровнями подачи дутья, которое соответствует высоте кислородной зоны $L_{12}=L_{\mathrm{\kappa}}=(0,175-0,20) D_{\text {в }}$.

Расстояние между двумя уровнями вдувания менее 250 мм неэффективно вследствие сокращения общей высоты кислородных зон или зоны перегрева расплава. Расстояние, составляющее более 250 мм между фурменными поясами, также неэффективно, так как в этом случае эндотермическая реакция восстановления $\mathrm{CO}_{2}+C=2 \mathrm{CO}-Q$ углеродом топлива успевает развиваться в области между первым и вторым уровнями фурм, что приводит к снижению как эффективной температуры источника тепла, так и температуры перегрева расплава шлака.

Анализ горения топлива показал, что чем больше высота кислородной зоны и меньше высота восстановительной зоны, тем сильнее перегревается расплав при движении от зоны плавления до горна.

Высота зоны восстановления уменьшается до минимума или практически будет отсутствовать, если на расстоянии 250 мм от первого уровня вдувания будут установлены фурмы второго уровня вдувания с площадью сечения всех отверстий на 5-10 \% меньше, чем фурм первого уровня. Первый уровень вдувания снабжен фурмами, площадь сечения отверстий которых составляет 52-57 \% общей площади сечения фурменных отверстий, соответственно, площадь сечения фурменных отверстий верхнего уровня составляет $48-43 \%$. Такое соотношение позволяет подавать примерно одинаковое количество дутья на оба горизонта зоны горения топлива, так как высота столба шихты, расположенного выше от второго уровня вдувания (рис. 1), всего на 5-10 \% меньше высоты столба от первого уровня [7].

Подогрев дутья интенсифицирует теплообмен в зоне перегрева расплава [5]. При подогреве дутья стойкость кокса против механического истирания и термического растрескивания не 
изменяется, а стойкость антрацита и тощих углей повышается. Плотность и модуль упругости антрацита на 30-40 \% выше, чем кокса, так как последний имеет большое количество пор, которые образуются в угольной шихте в процессе коксования за счет удаления влаги и летучих. Поэтому для снижения термических напряжений в кусках антрацита необходимо резко уменьшить градиенты температуры на его поверхности, что возможно при подогреве дутья, способствующего протеканию реакции

$$
\mathrm{C}+1 / 2 \mathrm{O}_{2} \leftrightarrow \mathrm{CO}+117 \mathrm{МДж/моль}
$$

вместо реакции

$$
\mathrm{C}+\mathrm{O}_{2} \rightarrow \mathrm{CO}_{2}+400,428 \mathrm{МДж/моль}
$$

что уменьшает температуру поверхности топлива в кислородной зоне, температурные градиенты и вероятность растрескивания антрацита. Оптимальным является подогрев дутья до $450-550{ }^{\circ} \mathrm{C}$. Температура ниже $450{ }^{\circ} \mathrm{C}$ недостаточна для эффективного подавления реакции (4) и развития реакции (3), температура поверхности куска антрацита в кислородной зоне остается высокой (около $2000{ }^{\circ} \mathrm{C}$ ), что будет еще вызывать значительные температурные градиенты, увеличивать вероятность растрескивания куска топлива.

Подогрев дутья до температур свыше $550{ }^{\circ} \mathrm{C}$ нецелесообразен, так как на шахтных печах меньших размеров устанавливаются радиационно-конвективные рекуператоры, в которых теплообменные трубы из жаростойкой стали выше этой температуры быстро выходят из строя. Более высокий и эффективный нагрев воздуха дают кауперы больших габаритов, их устанавливают для обслуживания шахтных печей большого диаметра.

При замене кокса антрацитом и тощими углями при использовании холодного дутья, как и при неоправданно завышенном уровне загрузки шихты, в конце плавки над фурмами образуются аналогичные козырьки, состоящие из шлака и угольной мелочи. Давление дутья и, соответственно, сопротивление столба шихты возрастают с 400 до 1200 мм в. ст. в начале и в конце кампании. Для исключения этих нежелательных явлений была уменьшена высота загрузки шахтной печи и применено подогретое дутье.

Эти мероприятия позволили снизить на 12-15 \% затраты на приготовление оксидного расплава, повысить температуру расплава на $25-30{ }^{\circ} \mathrm{C}$, что благоприятно повлияло на эксплуатационные показатели минераловатных изделий.

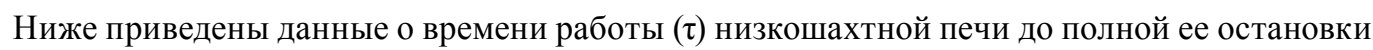
в зависимости от температуры подогрева дутья:

$\begin{array}{lllllll}t,{ }^{\circ} \mathrm{C} & \text { Без подогрева } & 100 & 200 & 300 & 450 & 550 \\ \tau, \text { сут } & 0,3 & 0,8 & 1,5 & 3,0 & 4,5 & 5,0 .\end{array}$

\section{Выводы}

Плавка чугуна и силикатных материалов в твердотопливной низкошахтной печи при использовании антрацита и тощих углей в качестве топлива возможна при уровне загрузки материалов в печь, равном $(2,5-2,8) \sqrt{D_{B}}$. Подачу в кислородную зону подогретого до $450-500{ }^{\circ} \mathrm{C}$ дутья необходимо осуществлять в равных количествах на двух горизонтах с расстоянием между ними, равным 250 мм. 
Работа выполнена в соответствии с заданием № 2014/213 на выполнение государственных работ в сфере научной деятельности в рамках базовой части государственного задания Минобрнауки России.

\section{Список литературы}

[1]. Пат. 89682 РФ, МПК F27B1/00, F23L15/04. Рекуператор вагранки / Пашков В.В., Селянин И.Ф., Феоктистов А.В. и др. - № 2009128152/22; заявл. 21.07.09; опубл. 10.12.09.

[2]. Пат. 89683 РФ, МПК F27B1/00. Рекуператор вагранки / Пашков В.В., Селянин И.Ф., Феоктистов А.В. и др. - № 2009128151/22; заявл. 21.07.09; опубл. 10.12.09.

[3]. Пат. 89684 РФ, МПК F27B1/00. Рекуператор вагранки / Пашков В.В., Селянин И.Ф., Феоктистов А.В. и др. - № 2009128149/22; заявл. 21.07.09; опубл. 10.12.09.

[4]. Пат. 99135 РФ, МПК F28D1/00. Рекуператор вагранки / Селянин И.Ф., Пашков В.В., Куценко А.И. и др. - № 2010125296/02; заявл. 18.06.2010; опубл. 10.11.10.

[5]. Селянин И.Ф., Феоктистов А.В., Бедарев С.А. Теория и практика интенсификации технологического процесса в шахтных печах малого диаметра. М. : Теплотехник, 2010. 379 с.

[6]. Чуханов 3.Ф. Некоторые проблемы топлива и энергетики. М. : Изд-во АН СССР, 1961. $479 \mathrm{c}$.

[7]. А.c. 1132130 CССР, МПК5 F27B1/16. Вагранка / И.Ф. Селянин, Г.Л. Маркс, Н.Г. Горбунов, А.Н. Кудрявцев - заявл. 20.06.1983; опубл. 30.12.1984. Бюл. 48. 